\title{
Reproducibility of pixel values for two photostimulable phosphor plates in consecutive standardized scannings
}

\section{Reprodutibilidade dos valores de "pixels" de duas placas de fósforo fotoestimuláveis em leituras padronizadas consecutivas}

\author{
Patricia Freitas* \\ Renato Yassutaka Faria Yaedú** \\ Izabel Regina Fischer Rubira-Bullen*** \\ Maurício Escarpinati**** \\ Marcelo Costa Vieira**** \\ Homero Schiabel ${ }^{* * * * *}$ \\ José Roberto Lauris ${ }^{* * * * *}$
}

\begin{abstract}
The objective of the present study was to determine the reproducibility of the pixel values obtained with the Digora system (Soredex, Finland). Exposures were standardized, with variation in exposure and scanning time of two photostimulable phosphor plates containing a stepwedge image. The smallest variation in pixel values ranged from 50 to $75 \%$, with the widest variations being observed in less dense steps. A significant difference in pixel values was observed in terms of X-ray exposure and scanning times and between the two plates themselves (ANOVA, $p<0.01$ ). Using the present methodology, the reproducibility of pixel values was not satisfactory for the tested white photostimulable plates. This wide variation in digitalization might be influenced by the amount of X-rays that sensitized the plates. It may be important to establish the reproducibility of the pixel values in quantitative studies using digital image.
\end{abstract}

DESCRIPTORS: Radiography, dental, digital; Reproducibility of results.

RESUMO: O objetivo do presente trabalho foi determinar a reprodutibilidade dos valores de "pixels" obtidos com o sistema Digora (Soredex, Finlândia). As exposições foram padronizadas, com variação no tempo de exposição e leitura de duas placas de fósforo fotoestimuláveis contendo a imagem de um penetrômetro. A menor variação nos valores de "pixels" foi de 50 a $75 \%$, sendo as maiores variações oriundas nas faixas mais claras. Uma diferença significante nos valores de "pixels" foi observada em relação ao tempo de exposição e leitura das placas e entre as duas placas (ANOVA, $\mathrm{p}<0,01$ ). Utilizando a presente metodologia, a reprodutibilidade dos valores de "pixels" das placas testadas do sistema Digora não foi satisfatória. Essa grande variação na digitalização pode ter sido influenciada pela quantidade de Raios X que sensibilizou as placas. Isso pode ser importante para estabelecer a reprodutibilidade dos valores de "pixels" em estudos quantitativos usando imagem digital.

DESCRITORES: Radiografia dentária digital; Reprodutibilidade dos resultados.

\section{INTRODUCTION}

Some digital radiographic systems use photostimulable phosphor plates, materials that emit light when exposed to another energy source (light, $\mathrm{X}$-rays). Commercially, this method was introduced in 1981 during the International Congress of Radiology, and the first study was published in $1983^{16}$. Since then, there have been great advances in imaging systems in general ${ }^{2}$.

Photostimulable plates have some advantages over conventional radiographic film, including the efficient formation of the latent image because these plates absorb more energy than conventional film, and thus require a shorter exposure time ${ }^{10}$. Finally, the image is obtained electronically, eliminating chemical processing, and the plates are also reutilizable ${ }^{6,11}$.

The signal resulting from a digital photostimulable phosphor imaging system might be affected by a low incidence of photons (short exposure) and thus generate a smaller number of luminescence centers, which in turn leads to a low signal. Con-

*DDS; **MS; ***PhD, Associate Professor - Department of Stomatology, School of Dentistry at Bauru, University of São Paulo.

**** MScs; ****PhD, Associate Professor - Department of Electrical Engineering, School of Electrical Engineering at São Carlos, University of São Paulo.

****** PhD, Department of Statistics, School of Dentistry at Bauru, University of São Paulo. 
Freitas P, Yaedú RYF, Rubira-Bullen IRF, Escarpinati M, Vieira MC, Schiabel H, Lauris JR. Reproducibility of pixel values for two photostimulable phosphor plates in consecutive standardized scannings. Braz Oral Res 2006;20(3):207-13.

sequently, there is an increase in photon noise, which causes a non-uniform density distribution. Another factor that might cause a reduction in the signal of this system is fainting of the latent image over time due to phosphorescence $e^{2,10,12,15,17}$. These two types of signal loss can compromise the pixel values attributed to a radiographic image.

Direct digital dental radiological systems offer the potential to radically change the way dentists diagnose and treat dentomaxillofacial diseases ${ }^{5,8,9,14,20}$.

The aim of this study was to determine the reproducibility of pixel values obtained with two plates from the Digora system (Soredex, Finland) in consecutive standardized scannings.

\section{MATERIALS AND METHODS}

Two photostimulable white plates (1 and 2) of the Digora system (Soredex, Orion Corporation, Tuusula, South Finland, Finland) measuring $35 \mathrm{x}$ $45 \mathrm{~mm}$, with an active area of $30 \times 40 \mathrm{~mm}$ and a specification of $416 \times 560$ pixels, were used. Each pixel possessed a specific spatial resolution of 71 x $71 \mu \mathrm{m}(6 \mathrm{lp} / \mathrm{mm})^{3,18}$. All plates were immediately scanned before each test to exclude any residual signal caused by environmental light during storage. The plates were kept protected from light throughout the process ${ }^{13}$. The Digora scanner must be calibrated at installation in order to relate the output of the X-ray unit to the scanner response. For the calibration, an imaging plate has to be exposed with the maximum exposure that will be tested, which in our situation was $0.5 \mathrm{~s}^{1}$. No extra pre-processing was used for the scanned radiographs. Furthermore, no image processing was done to enhance image quality other than the standard pre-processing provided by the system under investigation.

All exposures were done with the same X-ray device (Yoshida, Tokyo, Honshu, Japan) operating at $70 \mathrm{kVp}, 7 \mathrm{~mA}$, with a filtration of $2.2 \mathrm{mmAl}$. The exposure time was varied for each photostimulable plate as shown in Table 1. The focus-plate distance was $20 \mathrm{~cm}$ and five radiographic images and five readings were obtained for each plate. The plates were exposed with a stepwedge and soft tissue simulator (Figure 1). The soft tissue simulator was done using red wax $(17 \mathrm{~mm}$ thick, $45 \mathrm{~mm}$ wide and $35 \mathrm{~mm}$ high).

\section{Calculation of the reproducibility of pixel values (RP)}

The radiographic step image was digitized five times under identical conditions for the two plates in order to determine the inherent RP when assigning pixel values to the same grayscale steps ${ }^{7}$. After digitization, the standard deviation (SD) and mean pixel value were obtained using the ImageJ software (NIH, Washington, Maryland, USA). The histogram tool measured an area of 14,000 pixels for each step in every image (Figure 2). The calculation applied was (largest difference/mean) x 100. The largest difference was chosen between the largest number obtained from the difference between mean pixel value

TABLE 1 - Variation in X-ray exposure and scanning times.

\begin{tabular}{c|c}
\hline \hline Exposure time $(\mathrm{s})$ & Scanning time \\
\hline 0.05 & $5 \mathrm{~min}, 30 \mathrm{~min}, 1 \mathrm{~h}$ and $8 \mathrm{~h}$ \\
\hline 0.1 & $5 \mathrm{~min}, 30 \mathrm{~min}, 1 \mathrm{~h}$ and $8 \mathrm{~h}$ \\
\hline 0.2 & $5 \mathrm{~min}, 30 \mathrm{~min}, 1 \mathrm{~h}$ and $8 \mathrm{~h}$ \\
\hline 0.3 & $5 \mathrm{~min}, 30 \mathrm{~min}, 1 \mathrm{~h}$ and $8 \mathrm{~h}$ \\
\hline 0.4 & $5 \mathrm{~min}, 30 \mathrm{~min}, 1 \mathrm{~h}$ and $8 \mathrm{~h}$ \\
\hline 0.5 & $5 \mathrm{~min}, 30 \mathrm{~min}, 1 \mathrm{~h}$ and $8 \mathrm{~h}$ \\
\hline \hline
\end{tabular}

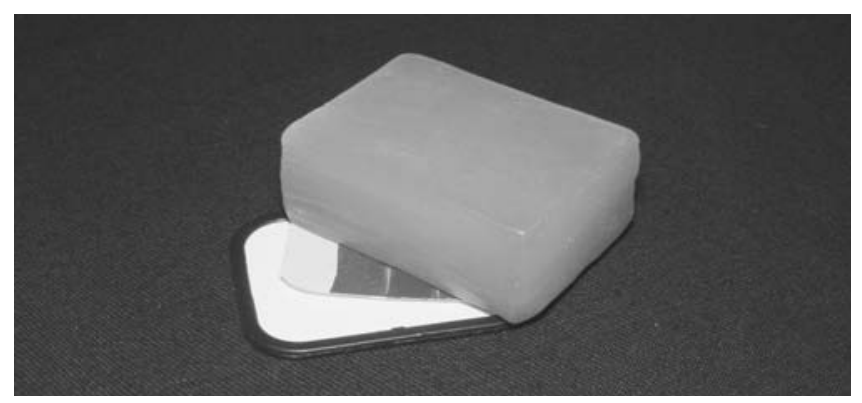

FIGURE 1 - A stepwedge and soft tissue simulator.
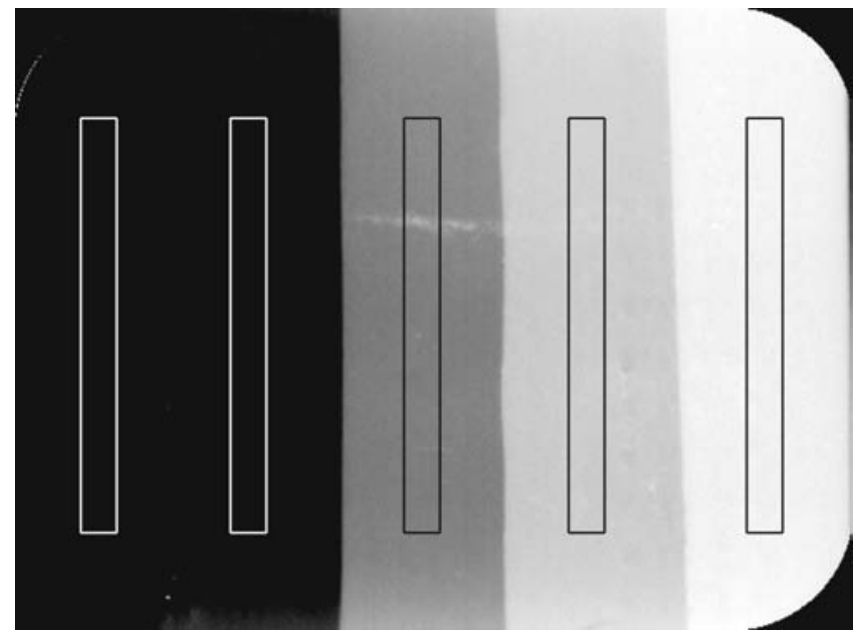

FIGURE 2 - Representation of the reading areas for the Digora plates. 
Freitas P, Yaedú RYF, Rubira-Bullen IRF, Escarpinati M, Vieira MC, Schiabel H, Lauris JR. Reproducibility of pixel values for two photostimulable phosphor plates in consecutive standardized scannings. Braz Oral Res 2006;20(3):207-13.

(of the five images) minus the smallest pixel value (of the five images) and the largest pixel value minus the mean. The smallest and the largest pixel values were obtained after five consecutive scannings of the plates. The mean pixel value was obtained from the five images scanned under the same conditions.

\section{RESULTS}

The final mean pixel values and the RP coefficient using different exposure and scanning times obtained for plates 1 and 2 are shown in Tables 2 ,
3, 4 and 5. The steps represent the five optical densities of the stepwedge, the mean corresponds to the five scannings of the photostimulable plates (plate 1 and plate 2), and RP is reported as a percentage.

Three-way ANOVA revealed a significant difference for scanning time of the plates $(p<0.000001)$, $\mathrm{X}$-ray exposure time $(\mathrm{p}<0.000001)$, and between plates $(p<0.01)$. Pairwise comparison of the above variables was significant for the scanning time and exposure time combination $(p<0.01)$. The other combinations were not significant at the $5 \%$ level.

TABLE 2 - Mean pixel values and the reproducibility of pixel values (RP) coefficient obtained for plates 1 and 2 using 5 minute scanning time and different X-ray exposures.

\begin{tabular}{|c|c|c|c|c|c|}
\hline Scanning - $5 \mathrm{~min}$ & Step & Mean plate 1 & RP plate $1(\%)$ & Mean plate 2 & RP plate $2(\%)$ \\
\hline \multirow{5}{*}{$\begin{array}{c}\text { Exposure time - } \\
0.5 \mathrm{~s}\end{array}$} & 1 & 11.37 & 97.00 & 6.41 & 100.00 \\
\hline & 2 & 34.25 & 76.00 & 19.02 & 100.00 \\
\hline & 3 & 85.53 & 85.00 & 50.45 & 82.00 \\
\hline & 4 & 203.48 & 25.00 & 156.70 & 22.00 \\
\hline & 5 & 255.00 & 0.00 & 255.00 & 0.00 \\
\hline \multirow{5}{*}{$\begin{array}{c}\text { Exposure time - } \\
0.4 \mathrm{~s}\end{array}$} & 1 & 17.90 & 59.00 & 9.46 & 133.00 \\
\hline & 2 & 41.37 & 43.00 & 30.49 & 110.00 \\
\hline & 3 & 91.74 & 51.00 & 76.98 & 92.00 \\
\hline & 4 & 190.27 & 34.00 & 176.39 & 45.00 \\
\hline & 5 & 254.99 & 0.00 & 255.00 & 0.00 \\
\hline \multirow{5}{*}{$\begin{array}{c}\text { Exposure time - } \\
0.3 \mathrm{~s}\end{array}$} & 1 & 6.37 & 100.00 & 1.21 & 400.00 \\
\hline & 2 & 23.25 & 100.00 & 5.28 & 400.00 \\
\hline & 3 & 59.07 & 74.00 & 27.77 & 137.00 \\
\hline & 4 & 153.21 & 17.00 & 151.88 & 8.00 \\
\hline & 5 & 255.00 & 0.00 & 255.00 & 0.00 \\
\hline \multirow{5}{*}{$\begin{array}{c}\text { Exposure time - } \\
0.2 \mathrm{~s}\end{array}$} & 1 & 4.10 & 100.00 & 0.00 & 0.00 \\
\hline & 2 & 21.31 & 116.00 & 0.00 & 0.00 \\
\hline & 3 & 65.02 & 95.00 & 21.60 & 26.00 \\
\hline & 4 & 178.18 & 43.00 & 141.54 & 8.00 \\
\hline & 5 & 255.00 & 0.00 & 255.00 & 0.00 \\
\hline \multirow{5}{*}{$\begin{array}{c}\text { Exposure time - } \\
0.1 \mathrm{~s}\end{array}$} & 1 & 2.07 & 175.00 & 1.19 & 400.00 \\
\hline & 2 & 11.58 & 154.00 & 5.64 & 400.00 \\
\hline & 3 & 42.99 & 75.00 & 32.38 & 124.00 \\
\hline & 4 & 151.47 & 14.00 & 143.52 & 16.00 \\
\hline & 5 & 255.00 & 0.00 & 255.00 & 0.00 \\
\hline \multirow{5}{*}{$\begin{array}{c}\text { Exposure time - } \\
0.05 \mathrm{~s}\end{array}$} & 1 & 1.29 & 400.00 & 0.00 & 0.00 \\
\hline & 2 & 5.86 & 400.00 & 0.00 & 0.00 \\
\hline & 3 & 26.99 & 274.00 & 12.80 & 100.00 \\
\hline & 4 & 130.30 & 30.00 & 126.10 & 82.00 \\
\hline & 5 & 255.00 & 0.00 & 209.10 & 0.00 \\
\hline
\end{tabular}


Freitas P, Yaedú RYF, Rubira-Bullen IRF, Escarpinati M, Vieira MC, Schiabel H, Lauris JR. Reproducibility of pixel values for two photostimulable phosphor plates in consecutive standardized scannings. Braz Oral Res 2006;20(3):207-13.

TABLE 3 - Mean pixel values and the reproducibility of pixel values (RP) coefficient obtained for plates 1 and 2 using 30 minute scanning time and different X-ray exposures.

\begin{tabular}{|c|c|c|c|c|c|}
\hline Scanning - $30 \mathrm{~min}$ & Step & Mean plate 1 & RP plate $1(\%)$ & Mean plate 2 & RP plate $2(\%)$ \\
\hline \multirow{5}{*}{$\begin{array}{c}\text { Exposure time - } \\
0.5 \mathrm{~s}\end{array}$} & 1 & 13.52 & 47.00 & 19.25 & 29.00 \\
\hline & 2 & 45.30 & 47.00 & 54.54 & 29.00 \\
\hline & 3 & 104.43 & 40.00 & 128.73 & 32.00 \\
\hline & 4 & 206.29 & 24.00 & 242.04 & 21.00 \\
\hline & 5 & 255.00 & 0.00 & 255.00 & 0.00 \\
\hline \multirow{5}{*}{$\begin{array}{c}\text { Exposure time - } \\
0.4 \mathrm{~s}\end{array}$} & 1 & 14.35 & 100.00 & 5.40 & 131.00 \\
\hline & 2 & 39.80 & 100.00 & 21.63 & 146.00 \\
\hline & 3 & 92.05 & 98.00 & 62.34 & 109.00 \\
\hline & 4 & 214.35 & 32.00 & 175.66 & 43.00 \\
\hline & 5 & 255.00 & 0.00 & 255.00 & 0.00 \\
\hline \multirow{5}{*}{$\begin{array}{c}\text { Exposure time - } \\
0.3 \mathrm{~s}\end{array}$} & 1 & 14.40 & 59.00 & 14.31 & 107.00 \\
\hline & 2 & 38.98 & 47.00 & 39.06 & 100.00 \\
\hline & 3 & 89.29 & 45.00 & 99.72 & 79.00 \\
\hline & 4 & 185.07 & 38.00 & 207.02 & 36.00 \\
\hline & 5 & 247.02 & 0.00 & 255.00 & 0.00 \\
\hline \multirow{5}{*}{$\begin{array}{c}\text { Exposure time - } \\
0.2 \mathrm{~s}\end{array}$} & 1 & 28.16 & 50.00 & 19.15 & 100.00 \\
\hline & 2 & 66.59 & 42.00 & 48.68 & 100.00 \\
\hline & 3 & 138.99 & 40.00 & 126.33 & 35.00 \\
\hline & 4 & 236.35 & 32.00 & 225.84 & 23.00 \\
\hline & 5 & 255.00 & 0.00 & 249.52 & 0.00 \\
\hline \multirow{5}{*}{$\begin{array}{c}\text { Exposure time - } \\
0.1 \mathrm{~s}\end{array}$} & 1 & 8.11 & 100.00 & 0.00 & 0.00 \\
\hline & 2 & 30.79 & 100.00 & 0.00 & 0.00 \\
\hline & 3 & 81.09 & 72.00 & 14.95 & 44.00 \\
\hline & 4 & 184.17 & 38.00 & 140.98 & 15.00 \\
\hline & 5 & 255.00 & 0.00 & 255.00 & 0.00 \\
\hline \multirow{5}{*}{$\begin{array}{c}\text { Exposure time - } \\
0.05 \mathrm{~s}\end{array}$} & 1 & 3.64 & 170.00 & 1.39 & 400.00 \\
\hline & 2 & 12.56 & 163.00 & 5.98 & 400.00 \\
\hline & 3 & 42.19 & 90.00 & 24.52 & 198.00 \\
\hline & 4 & 156.76 & 18.00 & 147.43 & 15.00 \\
\hline & 5 & 255.00 & 0.00 & 255.00 & 0.00 \\
\hline
\end{tabular}

\section{DISCUSSION}

No studies were available in the literature evaluating the digitalization variability or reproducibility of pixel values in direct or semidirect digital systems such as the Digora system. The present study demonstrated a systematic error in the consecutive digitalization of photostimulable plates which increased in value with decreasing $\mathrm{X}$-ray exposure time.

The studies evaluating images over time, for example, bone healing ${ }^{8,9,14}$, digital subtraction ${ }^{5}$ and densitometry ${ }^{20}$, all based on differences in the pixel values of images obtained at different times, may be affected by the variability of the digitalization process. A digitalization error (causing lack of reproducibility) of pixel values would be deleterious in these situations because it would attribute pixel values that differ from those corresponding to a true change that occurred in the patient.

Apparently, photon noise originating from Xrays may be one factor that could contribute to the large digitalization error observed for photostimulable plates of the Digora system ${ }^{4,6,17,18}$. As observed 
Freitas P, Yaedú RYF, Rubira-Bullen IRF, Escarpinati M, Vieira MC, Schiabel H, Lauris JR. Reproducibility of pixel values for two photostimulable phosphor plates in consecutive standardized scannings. Braz Oral Res 2006;20(3):207-13.

TABLE 4 - Mean pixel values and the reproducibility of pixel values (RP) coefficient obtained for plates 1 and 2 using 1 hour scanning time and different X-ray exposures.

\begin{tabular}{|c|c|c|c|c|c|}
\hline Scanning - $1 \mathrm{~h}$ & Step & Mean plate 1 & RP plate $1(\%)$ & Mean plate 2 & RP plate $2(\%)$ \\
\hline \multirow{5}{*}{$\begin{array}{c}\text { Exposure time - } \\
0.5 \mathrm{~s}\end{array}$} & 1 & 19.80 & 34.00 & 21.13 & 33.00 \\
\hline & 2 & 53.80 & 37.00 & 59.84 & 44.00 \\
\hline & 3 & 123.21 & 37.00 & 137.93 & 45.00 \\
\hline & 4 & 222.84 & 25.00 & 236.66 & 31.00 \\
\hline & 5 & 241.80 & 22.00 & 241.80 & 22.00 \\
\hline \multirow{5}{*}{$\begin{array}{c}\text { Exposure time - } \\
0.4 \mathrm{~s}\end{array}$} & 1 & 17.14 & 51.00 & 16.61 & 36.00 \\
\hline & 2 & 50.98 & 37.00 & 51.52 & 40.00 \\
\hline & 3 & 118.21 & 35.00 & 122.17 & 38.00 \\
\hline & 4 & 222.07 & 24.00 & 237.96 & 29.00 \\
\hline & 5 & 255.00 & 0.00 & 255.00 & 0.00 \\
\hline \multirow{5}{*}{$\begin{array}{c}\text { Exposure time - } \\
0.3 \mathrm{~s}\end{array}$} & 1 & 12.19 & 100.00 & 13.41 & 51.00 \\
\hline & 2 & 45.71 & 100.00 & 53.08 & 40.00 \\
\hline & 3 & 133.05 & 27.00 & 129.29 & 39.00 \\
\hline & 4 & 255.00 & 0.00 & 238.83 & 27.00 \\
\hline & 5 & 255.00 & 0.00 & 255.00 & 0.00 \\
\hline \multirow{5}{*}{$\begin{array}{l}\text { Exposure time - } \\
0.2 \mathrm{~s}\end{array}$} & 1 & 18.10 & 36.00 & 13.04 & 39.00 \\
\hline & 2 & 62.87 & 15.00 & 47.97 & 21.00 \\
\hline & 3 & 146.39 & 9.00 & 115.04 & 27.00 \\
\hline & 4 & 254.98 & 0.00 & 228.71 & 18.00 \\
\hline & 5 & 255.00 & 0.00 & 255.00 & 0.00 \\
\hline \multirow{5}{*}{$\begin{array}{c}\text { Exposure time - } \\
0.1 \mathrm{~s}\end{array}$} & 1 & 3.70 & 216.00 & 5.44 & 100.00 \\
\hline & 2 & 20.13 & 100.00 & 23.06 & 100.00 \\
\hline & 3 & 60.52 & 89.00 & 63.07 & 61.00 \\
\hline & 4 & 171.48 & 48.00 & 160.09 & 12.00 \\
\hline & 5 & 255.00 & 0.00 & 255.00 & 0.00 \\
\hline \multirow{5}{*}{$\begin{array}{c}\text { Exposure time - } \\
0.05 \mathrm{~s}\end{array}$} & 1 & 6.58 & 100.00 & 1.74 & 400.00 \\
\hline & 2 & 25.17 & 100.00 & 6.17 & 400.00 \\
\hline & 3 & 64.44 & 81.00 & 32.14 & 142.00 \\
\hline & 4 & 166.55 & 8.00 & 146.32 & 17.00 \\
\hline & 5 & 255.00 & 0.00 & 254.99 & 0.00 \\
\hline
\end{tabular}

in Table 2 through Table 5, the lower exposure times $(0.3 ; 0.2 ; 0.1 ; 0.05 \mathrm{~s})$ showed, in general, higher pixel variability. It may be possible that using a larger amount of soft tissue in the tests to absorb secondary radiation would improve these results, since a greater exposure time would be necessary. Another possible factor contributing to pixel value variability could be the $\mathrm{kVp}$ used, as stated by Tucker, Rezentes ${ }^{19}$ (1997). According to them, the largest variation in pixel values occurred at the lowest $\mathrm{kVp}$, thus the $\mathrm{X}$-ray beam quality has a significant effect on the pixel value.
Another finding of the present study was that the two photostimulable plates behaved differently in terms of the pixel values attributed to the same image. This result calls attention because it is possible that plates, although submitted to the same situation, could yield different results.

\section{CONCLUSIONS}

Using the present methodology, it was not possible to establish a satisfactory reproducibility of pixel values for the white photostimu- 
Freitas P, Yaedú RYF, Rubira-Bullen IRF, Escarpinati M, Vieira MC, Schiabel H, Lauris JR. Reproducibility of pixel values for two photostimulable phosphor plates in consecutive standardized scannings. Braz Oral Res 2006;20(3):207-13.

TABLE 5 - Mean pixel values and the reproducibility of pixel values (RP) coefficient obtained for plates 1 and 2 using 8 hour scanning time and different X-ray exposures.

\begin{tabular}{|c|c|c|c|c|c|}
\hline Scanning - $8 \mathrm{~h}$ & Step & Mean plate 1 & RP plate $1(\%)$ & Mean plate 2 & RP plate $2(\%)$ \\
\hline \multirow{5}{*}{$\begin{array}{c}\text { Exposure time - } \\
0.5 \mathrm{~s}\end{array}$} & 1 & 20.74 & 19.00 & 22.96 & 44.00 \\
\hline & 2 & 55.79 & 27.00 & 65.14 & 37.00 \\
\hline & 3 & 122.52 & 30.00 & 143.24 & 38.00 \\
\hline & 4 & 227.91 & 22.00 & 241.47 & 22.00 \\
\hline & 5 & 255.00 & 0.00 & 255.00 & 0.00 \\
\hline \multirow{5}{*}{$\begin{array}{c}\text { Exposure time - } \\
0.4 \mathrm{~s}\end{array}$} & 1 & 17.67 & 100.00 & 20.15 & 108.00 \\
\hline & 2 & 51.54 & 100.00 & 56.07 & 63.00 \\
\hline & 3 & 135.27 & 42.00 & 122.95 & 38.00 \\
\hline & 4 & 254.96 & 0.00 & 226.80 & 21.00 \\
\hline & 5 & 255.00 & 0.00 & 255.00 & 0.00 \\
\hline \multirow{5}{*}{$\begin{array}{c}\text { Exposure time - } \\
0.3 \mathrm{~s}\end{array}$} & 1 & 17.17 & 100.00 & 12.96 & 100.00 \\
\hline & 2 & 46.70 & 100.00 & 40.88 & 100.00 \\
\hline & 3 & 114.31 & 76.00 & 98.44 & 77.00 \\
\hline & 4 & 222.25 & 33.00 & 199.68 & 32.00 \\
\hline & 5 & 255.00 & 0.00 & 255.00 & 0.00 \\
\hline \multirow{5}{*}{$\begin{array}{c}\text { Exposure time - } \\
0.2 \mathrm{~s}\end{array}$} & 1 & 20.05 & 65.00 & 7.39 & 141.00 \\
\hline & 2 & 57.73 & 47.00 & 25.65 & 100.00 \\
\hline & 3 & 132.08 & 40.00 & 66.45 & 66.00 \\
\hline & 4 & 239.94 & 25.00 & 166.69 & 15.00 \\
\hline & 5 & 255.00 & 0.00 & 255.00 & 0.00 \\
\hline \multirow{5}{*}{$\begin{array}{c}\text { Exposure time - } \\
0.1 \mathrm{~s}\end{array}$} & 1 & 12.11 & 104.00 & 10.34 & 118.00 \\
\hline & 2 & 36.23 & 100.00 & 34.36 & 100.00 \\
\hline & 3 & 91.00 & 82.00 & 85.27 & 64.00 \\
\hline & 4 & 202.72 & 26.00 & 192.09 & 35.00 \\
\hline & 5 & 255.00 & 0.00 & 255.00 & 0.00 \\
\hline \multirow{5}{*}{$\begin{array}{c}\text { Exposure time - } \\
0.05 \mathrm{~s}\end{array}$} & 1 & 7.21 & 205.00 & 1.25 & 400.00 \\
\hline & 2 & 23.06 & 150.00 & 5.24 & 400.00 \\
\hline & 3 & 66.88 & 106.00 & 28.38 & 135.00 \\
\hline & 4 & 176.77 & 44.00 & 144.06 & 9.00 \\
\hline & 5 & 255.00 & 0.00 & 255.00 & 0.00 \\
\hline
\end{tabular}

lable plates tested. Those plates, under the circumstances tested, showed a wide variation in pixel values attributed to the same image even under standard conditions. These differences were statistically significant in terms of scanning time, X-ray exposure time and between the plates themselves. It is possible that photon noise originating from $\mathrm{X}$-rays may be the factor that contributed to the large digitalization error in this study.

\section{ACKNOWLEDGMENTS}

This work was supported by grants from the State of São Paulo Research Foundation (FAPESP04/04777-0). 
Freitas P, Yaedú RYF, Rubira-Bullen IRF, Escarpinati M, Vieira MC, Schiabel H, Lauris JR. Reproducibility of pixel values for two photostimulable phosphor plates in consecutive standardized scannings. Braz Oral Res 2006;20(3):207-13.

\section{REFERENCES}

1. Berkhout WER, Beuger DA, Sanderink GCH, van der Stelt $\mathrm{PF}$. The dynamic range of digital radiographic systems: dose reduction or risk of overexposure? Dentomaxillofac Radiol 2004;33(1):1-5.

2. Borg E, Attaelmanan A, Grondahl HG. Image plate systems differ in physical performance. Oral Surg Oral Med Oral Pathol Oral Radiol Endod 2000;89(1):118-24.

3. Borg E, Grondahl HG. On the dynamic range of different $\mathrm{x}$-ray photon detectors in intra-oral radiography. A comparison of image quality in film, charge-coupled device and storage phosphor systems. Dentomaxillofac Radiol 1996;25(2):82-8.

4. Bradford CD, Peppler WW, Dobbins JT $3^{\text {rd }}$. Performance characteristics of a Kodak computed radiography system. Med Phys 1999;26(1):27-37.

5. Bragger U, Hammerle CH, Mombelli A, Burgin W, Lang NP. Remodelling of periodontal tissues adjacent to sites treated according to the principles of guided tissue regeneration (GTR). J Clin Periodontol 1992;19(9 Pt 1):615-24.

6. Brettle DS, Workman A, Ellwood RP, Launders JH, Horner K, Davies RM. The imaging performance of a storage phosphor system for dental radiography. Br J Radiol 1996;69(819):256-61.

7. Escarpinati MC, Costa Vieira MA, Schiabel H. Computer technique for digital radiographic images correction based on the digitizer characteristic curve. J Digit Imaging 2002;15 Suppl 1:228-30. DOI 10.1007/s10278-0025082-1, 19 march 2002.

8. Ferreira Junior O, Damante JH, Lauris JR. Simple bone cyst versus odontogenic keratocyst: differential diagnosis by digitized panoramic radiography. Dentomaxillofac Radiol 2004;33(6):373-8.

9. Gegler A, Mahl C, Fontanella V. Reproducibility of and file format effect on digital subtraction radiography of simulated external root resorptions. Dentomaxillofac Radiol 2006;35(1):10-3.

10. Hildebolt CF, Fletcher G, Yokoyama-Crothers N, Conover GL, Vannier MW. A comparison of the response of storage phosphor and film radiography to small variations in X-ray exposure. Dentomaxillofac Radiol 1997;26(3):14751.

11. Kashima I. Computed radiography with photostimulable phosphor in oral and maxillofacial radiology. Oral Surg Oral Med Oral Pathol Oral Radiol Endod 1995;80(5):57798.

12. Martins MGBQ, Haiter Neto F, Whaites EJ. Analysis of digital images acquired using different phosphor storage plates (PSPs) subjected to varying reading times and storage conditions. Dentomaxillofac Radiol 2003;32(3):186-90.

13. Ramamurthy $\mathrm{R}$, Canning $\mathrm{CF}$, Scheetz JP, Farman AG. Impact of ambient lighting intensity and duration on the signal-to-noise ratio of images from photostimulable phosphor plates processed using DenOptix ${ }^{\circledR}$ and ScanX ${ }^{\circledR}$ systems. Dentomaxillofac Radiol 2004;33(5):307-11.

14. Sabbagh J, Vreven J, Leloup G. Radiopacity of resinbased materials measured in film radiographs and storage phosphor plate (Digora). Oper Dent 2004;29(6):677-84.

15. Seibert JA. Physics of computed radiography. Radiological Society of North America, 1996; Chicago, number 121.

16. Sonoda M, Takano M, Miyahara J, Kato H. Computed radiography utilizing scanning laser stimulated luminescence. Radiology 1983;148(3):833-8.

17. Stamatakis HC, Welander U, McDavid WD. Dose response of a storage phosphor system for intraoral radiography. Dentomaxillofac Radiol 1999;28(5):272-6.

18. Stamatakis HC, Welander U, McDavid WD. Physical properties of a photostimulable phosphor system for intraoral radiography. Dentomaxillofac Radiol 2000;29(1):2834.

19. Tucker DM, Rezentes PS. The relationship between pixel value and beam quality in photostimulable phosphor imaging. Med Phys 1997;24(6):887-93.

20. Wilkie JR, Giger ML, Chinander MR, Vokes TJ, Nishikawa RM, Carlin MD. Investigation of physical image quality indices of a bone densitometry system. Med Phys 2004;31(4):873-81.
Received for publication on Dec 26, 2005

Sent for alterations on Apr 05, 2006 Accepted for publication May 08, 2006 